\title{
Actors' Coalition Network in Supporting Islamic Education (Study on Basic Education in North Aceh District)
}

\author{
${ }^{1 s t}$ Nurhafni ${ }^{1},{ }^{2 n d}$ Sri Suwitri ${ }^{2}{ }^{3 r d}$ Endang Larasati ${ }^{3},{ }^{4 \text { th }}$ Kismartini. ${ }^{4}$ \\ \{nurhafni10882@gmail.com¹, sri_suwitri@yahoo.co.id², larasati57@gmail.com³ \\ kis_martini@yahoo.co.id ${ }^{4}$ \}
}

PhD Student, Departement of Public Administration, UniversitasDiponegoro Semarang, Indonesia ${ }^{1}$, Professor, Departemen of Public Administration, Universitas Tidar, Indonesia ${ }^{2}$, Professor, Departement of Public Administration,Universitas Diponegoro, Indonesia ${ }^{3}$, Lecture, Departemen of Public Administration, Universitas Diponegoro, Indonesia ${ }^{4}$

\begin{abstract}
The actor's coalitionnetwork was formed to support the effort of Islamic education through knowledge integration concept at basic education level in North Aceh Regency. It is a subsystem created from the interaction of all actors joined as the Subsystem Team which includes the regent of North Aceh, Office of Education and Culture of North Aceh and Office of Development and Planning (Bappeda) of North Aceh. The research objective is to describe and analyze actors coalition network in support of Aceh's Islamic value-based education policies, and recommend a model by referring to the actions of actors to create sustainable programs.The research employs a case study approach which is explanatory, and the data is analyzed descriptive qualitative to answer the research problem. The team was mandated to design an integration concept of basic education combining Islamic education and general sciences. However, the idea of integration has not been formulated specifically and systematically due to its constraints over some issues both in the context of the policy and practical level, especially, regarding the resource sharing availability issue. Responding to this situation, Dayah Education Office, Scholars Consultative Assembly, North Aceh Representative Council (DPRK), Mass media and other education stakeholders suggest the realisation of the integration concept by presenting a learning model to general education by adopting models and curriculum implemented in Dayah education since Aceh province has special right to implement education system respectfully to the local characteristics and local wisdom in Aceh. The results of this coalition networking was shown through a master plan for the integration of Islamic education and through the establishment of regional regulations both governor regulations or regent regulations where detail policy explanation is available for the implementation of the Islamic education within general schools in North Aceh District.The research concludes that there is no synergy between implementing agencies, the egosectoral, and the involvement of personal interests among the implementing agencies are still the issues. A common interpretation and the meaning of the implementation of Islamic values-based Aceh education policies can be achieved, however, the actors coalition network in supporting Islamic values-based education policies shows the lackness of coordination between the implementing agencies.
\end{abstract}

Keywords: policy coalition network, actors, Aceh Government Law, Islamic education 


\section{Introduction}

The implementation of special autonomy status is a manifest of the encouragement of democratic participation in order to accelerate the regional development. Law Number 11 Year 2006 about the Government of Aceh (LoGA) is a strong legal basis and umbrella for Aceh Province to accelerate the development in a post-conflict and Tsunami situation.

Policy networking is a term that is often used to give a message that there is no more decision-making process that is centralized (Heclo, 1978; Hanf and Scharpf, 1997). In the context of networking, power center is not the main an emphasis and the coordination pattern is not hierarchical (hierarchical authority) but rather bargaining and negotiating (horizontal bargaining). This relational pattern gives access to groups who have motivational values and interests to participate in the policy formulation process.

The grand design or model of the concept of Aceh's education policy based on Islamic values is a combination of religion (Islam) sourced from the Qur'an and hadiths and Aceh culturewhich is based on Islamic teachings, which are integrated with the National culture. Understanding the values is often formulated in different concepts. Schiro (2013) and Saminan (2013) say that values are normative benchmarks that influence humans in determining their choice between ways of acting in activities; deterministically Islamic education is more about how to carry out development in all fields that are encouraged by Islamic values, especially in the field of advancement of general knowledge and religion. (MPD, 2009: 9).

The research shows that, conceptually, there are weaknesses at the actorsnetwork in supporting Islamic education that is a different perspective between actors in interpreting the concept of Islamic education effort with very broad and complex indicators. Also, there is no technical guidance that createin consistencies between actors in the policy network. At practical level, the effort is interpreted to be more artificial concept rather to the substantive features of the Islamic education itself; for example activities tend to focus on the changes from school nomenclature into Arabic name or writing, local curriculum, uniforms, buildings, ornaments, and all school attributes adapted into Islamic characteristics at the school environment. Hence, there is no substantive effort of integrating Islamic education into the core system of teaching and learning process at school.

The reason for the research theme is that the policy advocacy network has not yet found a model that can accommodate Aceh's privileged values and the characteristics of the Acehnese people. Therefore, an Advocacy network is needed to be able to formulate Aceh policies based on Islamic values. For that reason, current research aims to answer the following questions: how to form an effective policy networking system in supporting Islamic education in basic education in North Aceh District?

\section{Islamic Education Policy}

Islamic education in the real sense is an education system that enables a person to direct life in accordance with Islamic ideals, so that he can shape his life in accordance with Islamic teachings. Islamic education is education based on the values of universal truth and the truth of God. God has prepared a clear educational foundation, which can enlighten as well as prosper and save humanity both for life in the world and the hereafter.

Islamic education is often referred to as "tarbiyah, ta`alim and ta`adib", these three terms contain profound meanings in the context of human relations with God, fellow humans, and human relations with the environment and the universe, Hasan Langgulung (1979) argues that Islamic education is a process of preparing young people to fill roles, transfer Islamic knowledge 
and values that are aligned with human functions. in the Koran surah Ar-Rum, verse 39, rabbayarubbu which means education means to improve, guide, master the affairs, guarding and maintaining.

Abdul Fattah Jalal (1977: 15-24) claims that the term ta`alim has a broader meaning than the meaning of tarbiyah, Athiyah Al Abrasy (1961: 27) defines that the Islamic education is an effort to prepare humans to live perfectly and happily, to love their motherland, well-established perfect physical mind and character, neatly organized mindset, smooth and professional feeling at work and sweet speech. Al-Attas (2001) mentioned that there are at least three elements that form and are involved in education, namely the existence of processes, content, and recipients, all of these elements can be concluded as something that is gradually implanted into human beings, thus guiding towards the recognition and recognition of the proper place of God in form and personality. In other words, Islamic education is where knowledge with charity must go hand in hand.

\section{Theory of Public Policy Networks}

The concept of policy networks is widely discussed by various parties, both by the government, scientists, business practitioners, and by the public in general to explain the importance of the presence of stakeholders from various backgrounds. Policy networks are formed at each stage of policy formulation. Jones (1984), Brewer, Howlett and M. Ramesh (1995) view formulation.consists of a series of stages, namely: 1) Alternative proposal stage; 2) Alternative selection; 3) Alternative assessments; 4) Alternative selection. The formulation of policies or the preparation of alternative policies is also the planning process (Quade, 1984: 108).

Lehmbruch (1984) argues that the concept of networks focuses on the relationship between state and non-state (industry, NGOs, interests groups, CSOs) and the pattern of relationships is based on interdependence. This relational relationship between various individual and collective actors is mainly due to the dependence on resources (Menzel, 1987). Generally organizations try to reduce the uncertainties (organizational uncertainties) faced by establishing relationships with other parties Thompson (1967).

\section{Theory of Advocacy Coalition Framework}

Advocacy Coalition Framework (ACF) Theory according to Sabatier and Jenkins Smith $(1998,1993,1999)$. ACF is more a theory of policy making that develops to solve public policy problems (ACF Weible and Sabatier chapter in Fischer et al. 2006). ACF is more a theory of continuity than a theory of change (Mintrom\&Vergari, 1996). The indicators of the ACF theory can be seen in the picture below: 


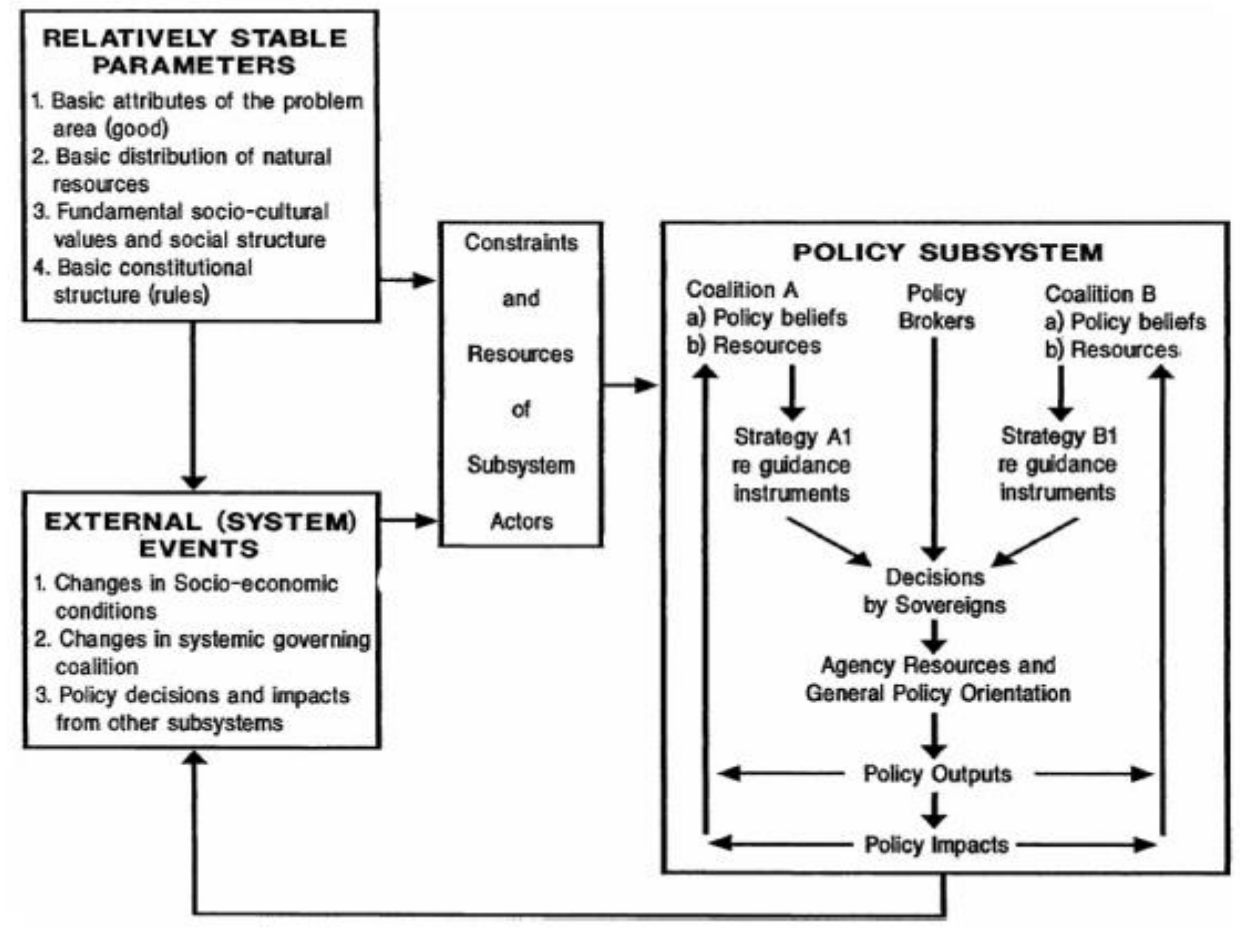

Figure 1.Advocacy Coalition Framework by Sebastier 1998:102

Social capital is generally defined as trust and reciprocal norms that help strengthen cooperative relations (Coleman 1990; Putnam et al, 1993). If both aspects (policy trust and social capital) greatly influence the structure of the network, then the network must show an advocacy coalition consisting of actors with the same belief system that is assembled by high social capital.

This view responds to old criticism that ACF does not have an individual collaboration model to support the belief system similarity argument (Schlager 1995). Social Capital Theory is centered on how collaboration is supported by trust, norms of reciprocity, and community involvement. Networking is an important basis for the idea of social capital because it shows opportunities for informal interaction, involvement in social activities, and the potential to bridge relationships between different groups (Putnam 2000). 


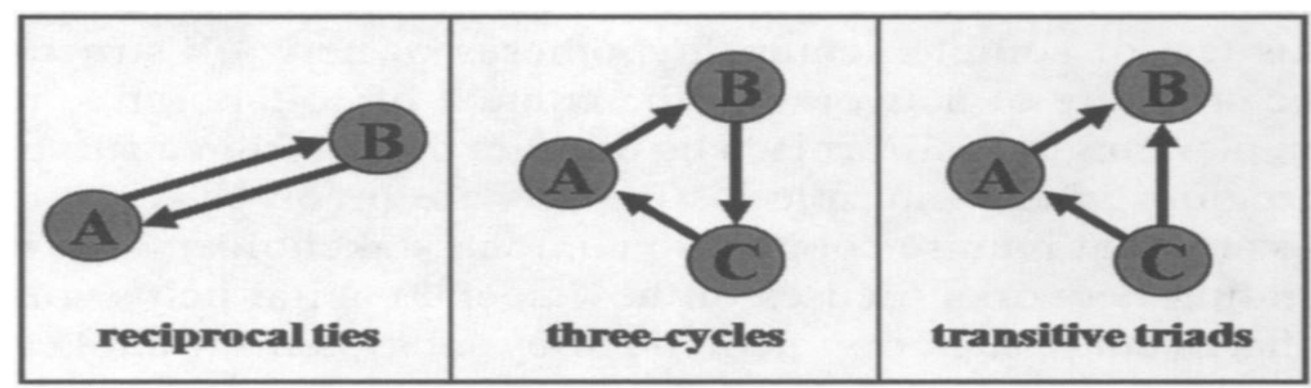

Figure 2. The effect of Social Capital Network and Its Configuration

\section{Sources: Lin 1999,;Portes 1998}

Building a history of mutual cooperative behavior is very important for the development of trust and a willingness to continue collaborating in facing the problem of collective action (Ostrom 1998). In network terms, "homophily" refers to the tendency to form relationships with similar individuals (McPherson, Smith-Lovin, and Cook 2001). the term "homophily trust" ACF hypothesis that actors will systematically look for collaborators who have the same ideology. (Innes 1978; Lord, Ross, and Lepper 1979; Munro and Ditto 1997; Munro et al., 2002). Assimilation bias is considered to give birth to distrust between actors who have very different belief systems because their analysis filters will interpret evidence that is relevant to policy in different ways.

\section{Methodology}

This research uses the theory of Robert K.Yin, with a case study research approach that was complemented by several data collection techniques, The research is descriptivequalitative analysis. This approach is used to determine the characteristics of policies as well as the hindrance and supporting aspects, based on the perspective of the implementers, functions, structures, roles of conduct, actor strategies, and power based on facts by presenting phenomena in the field comprehensively and holistically on the studied aspects. The analysis is used by connecting the hindrance theory and the support of implementation policy and actor-network theory that can provide information about the research phenomenon. The first stage of research was based on empirical data on field phenomena, there was a problem between the actorsnetwork coalition and implementing agencies in the implementation of Islamic values-based Aceh education policies so that it caused the different interpretations of understanding, and in the meaning of the program, thus, it raised the research questions on how are coalition networks between actors in supporting Islamic education in basic education in Aceh Utara District, the field study is based on triangulation of literature review, field studies, and documentation.

Data collection techniques are carried out by direct observation in the field regarding the activities of implementing agency actors, which is the legislative body who is in charge of the education commission, executive, Aceh education council, and regional education council, as well as education authority of Islamic boarding school, school authorities such as school principals, teachers and students, and involved institutions in improving the quality of education such as the education authority, teacher organization, and educational quality assurance 
institutions. The activities observed were the implementer's understanding of the program, the application of program activities in basic education, and Islamic teaching methods.

Furthermore, the data was obtained from in-depth interviews with purposive sampling and focus group discussions. The determination of informants was carried out using the snowball technique, that the selection of informants was flowed from one informant to the next. The Data was also gathered from documentation, guidelines, or Standard Operational Procedures (SOPs), and statistical records carried out by units or organizations. The Data is analyzed based on descriptive qualitative and explorative analysis, that is describing the collected research data, and this research employed a multi-case study design, the data analyzed concerned the actors and the roles of actors regarding the understanding and assessment of the program.

\section{Findings And Discusion}

\section{Islamization of Education Program}

Programs that have been implemented to support the efforts of Islamization of education in basic education in North Aceh District, are with the integration of religious education and general education, based on the regulation of Law Number 11 of 2006 concerning the Government of Aceh, and strengthened by North Aceh Qanun Number 4 of 2012, concerning the implementation of education, then certainly the administration of education in Aceh will not come out of the context of Islamic law.

Then to examine the multi-actor network in the effort to Islamize the theory education that is suitable to be used is a policy network with a coalition advocacy framework (ACF) method where the method is able to examine in dynamic and conflicting situations and offers to bridge the gap between formulation and policy implementation that occurs in the middle Public. The explanation above, it can be explained that the inhibiting and supporting factors in the qanun for the implementation of education through the Aceh education system based on Islamic values in basic education in North Aceh District can be explained as follows:

Tabel 1. Inhibiting and Supporting Factors of actor coalition networks in the Islamization of education efforts (processed by researchers)

\begin{tabular}{cccc}
\hline No & Obstacle Factors & No & Supporting Factors \\
\hline 1 & Resource & 1 & Policy Rules \\
2 & Regime Characteristics & 2 & Interest \\
3 & Availability of facilities and & 3 & Cross-sector communication \\
4 & infrastructure & 4 & Elite Actor \\
5 & Managing Actor & & \\
\hline
\end{tabular}

Crucial factors obtained from the research results, the inhibiting factors of the actor coalition network include resources, regime characteristics, availability of facilities and infrastructure, as well as implementing actors and policy accuracy, while the supporting factors of the coalition network of actors in the Islamization of education policies are policy rules, interests, cross communication. sector as well as elite actors. Based on the research results, the crucial factors in the Aceh education policy coalition based on Islamic values. 
Table 2. Program and Activities of District Education Office of Aceh Utara 2019

\begin{tabular}{|c|c|c|c|c|}
\hline No & School Management Program & Funding & Expected Outcomes & Budget Needed \\
\hline 1 & $\begin{array}{c}\text { National Examination Program, } \\
\text { School Exams and National } \\
\text { Standardized Exams for SD and SMP }\end{array}$ & APBK & 24.944 Students & 757.248 .000 \\
\hline 2 & $\begin{array}{l}\text { Re-enrollment of Dropped-out } \\
\text { Students (Retrieval Program) }\end{array}$ & APBK & 91 Students & 104.580 .600 \\
\hline 3 & $\begin{array}{l}\text { Islamic Education Integrated } \\
\text { Curriculum Development }\end{array}$ & APBK & $\begin{array}{c}\text { Curriculum } \\
\text { Documents and } 5 \\
\text { Sillabus and Moduls }\end{array}$ & 413.377 .440 \\
\hline 4 & $\begin{array}{l}\text { Recruitment and Teacher Training } \\
\text { Program for Islamic Education }\end{array}$ & APBK & 535 Teachers & 1.483 .235 .040 \\
\hline 5 & $\begin{array}{l}\text { Islamic Education Integrated } \\
\text { Curriculum Implementation Project }\end{array}$ & APBK & 493 Schools & 2.183 .391 .600 \\
\hline
\end{tabular}

The table shows the Islamization of education policy efforts are still general are less modified with programs that are up to date with the times that are able to actualize the results of values to students, the role of the implementing agency network in supporting Islamization of education efforts in basic education in North Aceh District.

The concept of networks pays attention to how policies emerge from interplay between people and organizations in providing a more informal picture of how "real" policies are implemented. (Parson, 2011: 187). The real picture of the Islamization of education efforts from the policy network is still at the stage of equating perceptions and understandings between legislative and executives and related agencies in this matter the regional education council, the North Aceh Education Office and Bappeda, the Education Office Dayah, the Scholars Consultative Council and the NGOs concerned with education of the respective institutions, experienced different views in interpreting the activities or programs of the Islamization of education efforts.

In the context of the implementation of Islamic education Qanun implementation based on Islamic values, measuring the substance of the policy message can be seen through: a) the amount of funds allocated, can show the seriousness of the implementation of the policy then b) the form of the policy, which explains the contents of the policy clarity, consistency of implementation, frequency implementation and receipt of messages correctly.

Based on the above indicators it is interpreted that the form of the contents of Islamic education policy is still general in nature, because there are no more detailed regulations such as the regulations of the regent and technical guidelines for the implementation of the program, this is one of the factors that hinder the efforts of Islamization of education, so that the implementing actors lack consistency in addressing the Islamization of education policy, so that the activities of the program carried out still received responses as well as diverse understandings and meanings among implementing agencies. 


\section{Executives (Regent)}

Policy networks will be contained within organizations which are often called policy subsystems. Howlett and Ramesh (1995: 125). Policy subsystems in policy formulation are formed when all the leaders and those led, between various political groups, the public and the private sector participate and interactions occur between participants or actors. The interplay between actors will form relatively stable parameters.

According to the monitoring and evaluation of the North Aceh Regency education office so far the Islamization of education effort is expected to be able to integrate the curriculum of religious education and general education, where the Islamization policy is able to actualize Islamic values and understanding of the characteristics and wisdom of the people of Aceh, based on field results where it was found that The implementation of Aceh's religious and cultural values has not been integrated as a whole in the education curriculum in Aceh with the following indicators:

a) The Islamization of science in general education shows that the values of Aceh's religious and cultural sciences have not been accommodated in social sciences in basic education in North Aceh District.

b) The religious and cultural values of Aceh cannot be represented in language subjects, except for Arabic and Acehnese subjects.

c) Religious values are more easily represented in art or culture subjects.

As for what distinguishes general subjects from Islamic-based education is from additional subjects such as fiqh, al-quran, and hadith subjects, which reflect the local wisdom of Acehnese education, there are several efforts that can be made to link Islamic values in the integration of religious and scientific sciences general, these efforts include. Designing the linkages between religious and general sciences. The linkage between these sciences and Islamic values. In integrating various scientific disciplines with Islamic teachings can be done implicating Islamic values into every subject.

The design of Islamic concepts for scientific disciplines for example, Islam for social knowledge, Islam for the arts, etc. are available in many ways for a long time ago. Furthermore, the Bappeda and the education office interpret theIsalmization of education effort with the implementation of an integrated curriculum, while the district head and the legislature interpret the effort for Islamic education by presenting Dayah teachers in general education, because the policy finds that education programs through education Islamization efforts, add to the burden on the region in pay honorariums for Dayah teachers so that the policy raises budget inefficiencies, plus the quantity of nearly three thousand more teachers in basic education in North Aceh District are still honorary; from 13,175 teachers, 33.99\% are non-civil servants, while the details are as follows: 


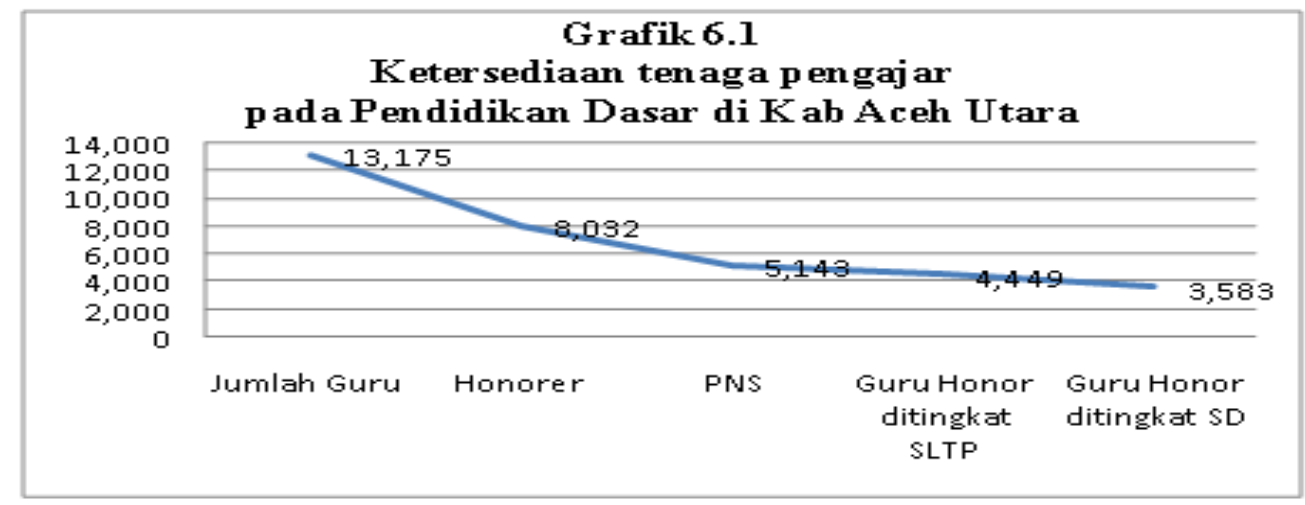

From the large number of educators in general education, each teacher has 9 students, 1 teacher should have 20 students, the Regional Development Planning Agency (Bappeda) and the local Education Office recommend to the regent for to make a policy to present Dayah teachers substituting general subjects teachers at basic education institutions. However, these activities did not get a positive response from the North Aceh Ulema Consultative Council and the Dayah Education Office because they felt that the process of Islamization of education should be taught by educators who understood the integration of science, and had special abilities in the field of religion because there are many differences between education in Dayah and education in general education. Then according to the North Aceh Regency Bappeda, that according to the rules that the provisions of the funds disbursed for the success of Islamic education activities namely through regional income and expenditure sources (APBD), Acehbased Islamic education activities cannot be taken from plots of other budget sources for example from school operational assistance, because it can violate the rules.

\section{Regional Education Council}

The rules of the Aceh education council institution are to have full authority and authority on problem solving in the field of education, but the authority and authority possessed cannot yet be fully exercised, so it is more impressed that the regional education assembly as a technical implementing agency carries out the policy, not as an input provider for officials elites.

Based on the results of the study shows that the authority and authority of the organization or implementing agency has not been fully able to optimally utilize its authority, because often the input provided to the authorized officials especially the regent has not been received directly, such as ratification of the regent's Qanun draft regulations on Islamic education until now Qanun has not yet been approved by the regent.

Although the policy was originally based on the proposal of the district head, who was urged by Acehnese Scholars leaders and the legislature to immediately pass a regulation Based on the graph above, it can be described that the number of honorary teachers is still very high, this problem will have an impact on the level of teacher welfare, a very ironic problem is that the provision of honorarium for pure and service honorary teachers only receives a monthly income of around 600 thousand which is paid every three months, a very low salary will find it difficult to demand a heavy workload, therefore it is very difficult to demand optimal results if it is not accompanied by adequate welfare needs. . 
Regional education councils interpret Islamic education or Islamization of education efforts by requiring elementary school students to be able to read Al-Qur`an and associate subjects with hadith according to the Islamic context. There are several draft Qanuns (RAQAN). proposed by the regional education council and have not yet been endorsed by the executive while the draft Qanun includes: In this case it can be seen that the weak coordination in the ratification of the draft Qanunshould not be made as a tug of war that causes the implementation policy not to go in line with policy expectations, then good coordination of all stakeholders is urgently needed especially from the main implementers responsible for implementation, need to understand mechanism of work involving all stakeholders involved in implementation.

\section{Legislative (District Representative Council)}

According to Goggin et al (1990: 20-21,31-40), the success of implementing performance can be seen through several indicators including, 1) encouragement and coercion at the federal level, 2) central / state capacity, and 3) encouragement and coercion in central and regional level. indicators of encouragement and coercion at the central level are highly dependent on legitimacy and credibility, that is, the more valid policies issued by the central government in the eyes of local governments, the greater the credibility, and vice versa.

Changes in interactions between actors caused by changes in the value system will result in changes in the policy subsystem. (Parsons, 2005: 198 adapted from Sabatier, 1988, 1991) The absence of ratification of the regent's regulations has become one of the obstacles in the actualization of Islamic values-based education, the actions of the legislature who continue to urge the regents to ratify the regulation until now has not produced results, so that the programs Islamic value-based education is still spelled out in the general routine of annual activities, while the draft Islamic education regulation draft has been drafted during the initial period of the current regent's office, but until now two terms of office have not been ratified. other education policies that are urgent to be ratified which are the words of the stakeholders of the policy (Purwanto and Sulistyastuti, 2012; 153). The actors involved in the policy process from both government and non-government circles are not free from values and interests (Islamy: 2000).

\section{Non-governmental Organization}

The Dayah Education Office and the Scholars Consultative Council According to Sabatier and Jenkins-Smith (1993) the framework of the advocacy coalition of actors with the same belief system, has a greater likelihood of forming a coalition, which leads to policy subsystems that are fragmented into ideological groups. As for the coalition that was built between the Islamic Education Office and the Scholars Consultative Council, it became an ideological group with the issuance of Law 44 of 1999 to Law number 18 of 2001 concerning the special autonomy of Aceh Province.

The substance of education policy in Aceh's education pattern based on Islamic values in accordance with the Islamic sharia context which is in lone with education in Dayah or Pesantren. According to the head of the North Aceh Scholars Consultative Council explained that there are limitations to the privileges given to Aceh Province in the implementation of Islamic education based on Islamic values in formal education, among 43 hours of subjects only 4 hours are given privileges, then stakeholders power is less serious in making decisions about the Islamization of education, such as the policy to include Dayah schools but what should be the pattern of education in general education by applying values such as Dayah education is one of the ways general education subjects are reduced by a number of subjects that are not too 
basic, then the teacher / teaching staff who are in charge of Islamic subjects as well as teaching staff who have Islamic qualifications and competencies, it is expected that the educational policies that are raised are able to restore the glory of education in Aceh like the royal period IskandarMuda, it requires commitment and synergy in all levels of Acehnese officials sitting together to restore the glory of Aceh's education.

The network developed between the local government and non-governmental organizations concerned with education has been going well. Activities carried out by the regional government are always asking for input from external parties or institutions, but according to the Chairperson of the North Aceh Indonesian Teachers Association, teacher professional institutions are not provided access to contribute and criticize government policies for the advancement of education, so far the training programs for teachers run by the North Aceh District education office are not very up to date with the times, one of which has become a discourse and the discussion has never been completed is about teacher equity programs , annual program proposals are still general and annual activities are not modified, so that the targets and targets of educational achievement both locally and nationally have not shown improvement in student achievement, besides that there are Qanun that have been ratified but not implemented. Moreover, the curriculum design processhas never involve the participation of teacher institutions.

\section{Conclusion}

Based on the research findings, it can be concluded that the form of a policy network system in supporting the efforts Isalmization of education in basic education in North Aceh Regency has not run synergies across sectors, advocating networks built are still in the context of interpretation which is vary across sectors, Islamization networks regarding the implementation of education in general education has not shown special treatment and emphasis especially on regulations, which are different from other regions, because the education administration system is still bound and fragmented with central education policies, where the Islamization of education in general education is very minimum to provide special space for local-based Islamic curriculum. Especially, the contents material taught is still general, this is due to the lack of additional time available for the local curriculum. Besides, another problem is limited availability of materials and adequate learning toolsas well as the low competence and qualifications of educators who master the Islamization of science.

As for analysis. achievement of the priority scale implemented in the form of a program because it shows a lack of seriousness and still weak coordination between implementing agencies, this is illustrated by the fact that there are still differences in interpretations between implementers, so that it has an impact on not having legalized derivative regulations from the Islamization of education, because there is no agreement by each actor.Then the meaning of the program is still interpreted in various ways by the implementing agency, because the relationship between the implementer and the bureaucratic structure has not shown synergy in understanding and interpreting the Islamization of education, the actor's accessibility in program implementation is still limited to the authority of certain institutions appointed by the authorized officials, so that the authority and authority of the institution implementers are not yet fully capable of being able to be transmitted optimally to the right personnel in accordance with the targets and policy directions, because often the input given by implementing agencies to elite officials has not been followed up, so that program implementers 
seem trapped by national education policies. so that the understanding and interpretation of the direction of the Islamic-based Aceh education policy is interpreted by the implementing agency in the context of providing reading material and reading short verses before and after learning, then every Friday a joint yasin reading is held, the Islamization of education is still limited to these activities, so that the proposed annual program does not specifically reflect the Islamic program

\section{Suggestion}

The roles of actors in realizing theIslamization of education efforts can be implemented if all stakeholders can form the same point of view regarding integrated education where all interested parties are able to actualize the results of science from Islamic education perspectives by respecting the local values and Islamic values through minimizing conflict of interests of actors and implementing institutions.

The advocacy network toward Islamizationof education efforts can be implemented optimally if the inhibiting factors are changed into supporting factors for example through the integration of cross-sector communication actors such as scholars and govermentactors as well as implementing agencies to improve the implementation of Aceh's special autonomy policy through the Law No. 11 of 2006 about the Aceh governance.

\section{Reference}

[1] Al- Attas Naquib Syed Muhammad. 2001. Islam and the Philasophy of Science.

[2] Abrasyi, Muhammad Athiyah al-, Dasar-dasar Pokok Pendidikan Islam, Terjemahan Bustamy A. Gani dan Djohar Bahry, (Jakarta: Bulan Bintang, 1985)

[3] Coleman, J.S. 1990. Foundations of Social Theory. Cambridge, MA: Harvard University Press

[4] Fischer, F. (1995). Evaluating Public Policy. Belmont, CA: Wadsworth.

[5] Heclo, Hugh.1978.Issue Network and The Executive Establisment, dalam Anthony King Ed The New American politicalSystem.Washinton Dc: American Interprise Institute

[6] Howlett, Michael and M. Ramesh. 1995. Studying Public Policy : Policy Cycles and Policy Subsystems. Oxford University Press, Oxford.

[7] Jalal Abdul Fattah, 1977. Min al usul at tarbiyah fii al-islam, Dar al Fikr, Beyrut

[8] Langgulung Hasan, 1979. Falsafah Pendidikan Islam, Jakarta: Bulan Bintang. Jakarta

[9] Larsen,R.J dan Eid, M (2008) Ed Diener and The Scienceof Subjective Well-Being.In Eid, M dan Larsen,J.R(Eds).The Science of Subjective Well Being. New York: The Guilford Press

[10] Menzel, C Donald (1987). An Interorganizational Approach to Policy Implementation. Public Perspectives. State University of New York Press, Albany, United State of America. Political Research., (21): 181-205.

[11] Ostrom, E. 1999. Social Capital: a Fad or a Fundamental Concept? Dalam P. Dasgupta \& I. Serageldin (Eds.), Social Capital: A Multifaceted Perspective. Washington, D.C: The World Bank. Pp. 172-214.

[12] Putnam, R.D., Leonardi, R., \& Nanetti, R.Y. 1993. Making Democracy Work: Civic Traditions in Modern Italy. Princeton, NJ: Princeton University Press

[13] Quade, E.S. 1982. Analysis for Public decision. Elsevier Science Publishing, New York 
[14] Sabatier, P. A., \& Jenkins-Smith, H. C. (1993). Policy Change and Learning: An Advocacy Coalition framework. Boulder: Westview Press.---------------. "Top down and Bottom up Approaches to Implementation Research" Journal of Public Policy 6, (Jan), h. 21-48

[15] Schlager, E. (1995). Policy making and collective action: Defining coalitions within the advocacy coalition framework. Policy Sciences, 28(3), 243-270. http://doi.org/10.1007/BF01000289

[16] Schiro, Michael Stephen. 2013. Curriculum Theory Conflicting Visions and Enduring Concerns. Los Angeles: Sage Publication

[17] Thompson, James D. 1967 Organizations in Action. New York: McGraw-Hill.

[18] Yin Robert K. (2006). Studi Kasus; Desain \& Metode. PT Raja Grafindo Persada, Jakarta

[19] Undang-Undang Nomor 11 Tahun 2006 tentang Pemerintah Aceh

[20] Qanun No 4 Tahun 2012 tentang penyelenggaraan pendidikan Kabupaten Aceh Utara 